\title{
PENGARUH PELATIHAN DAN PEMBINAAN TERHADAP PENGEMBANGAN USAHA KECIL
}

\author{
Rina Irawati \\ Dosen STIE Malangkuçeçwara Malang
}

\begin{abstract}
:
Small businesses have a central role in the Indonesian economy. Small businesses have supporting economic sector development. The large number is unfortunately not accompanied by the maximum quality of education from SMEs. To develop a small business, of course, training and coaching are required. The purpose of this study was to examine the effect of training and coaching simultaneously and partially on the development of small business. The sample of this research is 76 small medium entrepreneurs in Lowokwaru Malang, with purposive sampling technique. The result of multiple regression test proves that there is influence simultaneously and partially between training and coaching to small business development. It means research hypothesis was accepted. The dominant variable that influences is coaching (X2) with the largest beta value of 0.675 .
\end{abstract}

Keywords: Training, Coaching, Small Business Development

Abstrak:

Usaha kecil memiliki peran sentral dalam perekonomian Indonesia. Usaha kecil mendukung pengembangan sektor ekonomi. Jumlah yang besar sayangnya tidak disertai dengan kualitas pendidikan maksimal bagi UKM. Untuk mengembangkan usaha kecil, tentunya diperlukan pelatihan dan pembinaan. Tujuan dari penelitian ini adalah untuk menguji pengaruh pelatihan dan pembinaan secara simultan dan parsial terhadap pengembangan usaha kecil. Sampel penelitian ini adalah 76 pengusaha kecil menengah di Lowokwaru Malang, dengan teknik purposive sampling.

Hasil uji regresi berganda membuktikan bahwa ada pengaruh secara simultan dan parsial antara pelatihan dan pembinaan terhadap pengembangan usaha kecil. Artinya hipotesis penelitian diterima. Variabel dominan yang mempengaruhi adalah pembinaan (X2) dengan nilai beta terbesar 0,675. Kata kunci: Pelatihan, Pendampingan, Pengembangan Usaha Kecil

\section{PENDAHULUAN}

Usaha kecil sebagai kegiatan ekonomi rakyat memiliki peran sentral dalam perekonomian Indonesia. Walau krisis ekonomi telah memporakporandakan kehidupan bidang usaha besar dan menengah, ternyata usaha kecil tetap tegar dan berjalan marak di kawasan kehidupan ekonomi tingkat bawah (Glendoh, 2001). Di Indonesia usaha kecil menengah adalah tulang punggung perekonomian. Jumlah UKM sampai dengan tahun 2014 adalah 57,9 juta. Tahun 2016 diperkirakan jumlah pelaku UKM terus bertambah. Peranan UKM di Indonesia sangat besar karena menyumbang $60 \%$ dari PDB dan menampung 97\% tenaga kerja.

Usaha kecil memiliki potensi yang nyata dalam menunjang pembangunan di sektor ekonomi. Antara lain: (1) Menyerap tenaga kerja, (2) Penghasil barang dan jasa pada tingkat harga yang terjangkau bagi kebutuhan rakyat banyak yang berpenghasilan rendah, dan (3) Penghasil devisa negara yang potensial, karena keberhasilannya dalam memproduksi komoditi non migas. Karena perannya tersebut, maka usaha kecil perlu terus menerus dilatih dan dibina secara berkelanjutan agar dapat lebih berkembang dan maju.

Untuk mengembangkan usaha kecil, tentu saja dibutuhkan pelatihan. Menurut Sikula, 1976 dalam Susilo et.al (2014), pelatihan merupakan proses pendidikan jangka pendek yang menggunakan prosedur sistematis dan terorganisir sehingga tenaga kerja non manajerial mempelajari pengetahuan dan ketrampilan teknis untuk tujuan tertentu. Pembinaan juga memiliki arti penting dalam mengembangkan usaha kecil. Pembinaan merupakan proses atau pengembangan yang mencakup urutan-urutan pengertian, diawali dengan mendirikan, menumbuhkan, memelihara pertumbuhan tersebut yang disertai usaha-usaha perbaikan, menyempurnakan dan mengembangkannya (Rasyid et al, 2002 dalam Alhempi, Raden, 2013). Sasaran dari pembinaan usaha kecil menengah adalah untuk mengembangkan usahanya menjadi lebih besar.

Obyek penelitian ini adalah usaha kecil yang berada di Kelurahan Lowokwaru Malang, dimana kelurahan ini menjadi salah satu daerah binaan Posdaya STIE Malangkucecwara Malang "Mentari Jaya" sejak 5 tahun terakhir. Kelurahan Lowokwaru memiliki 13 Rukun 
Warga yang tersebar mulai dari wilayah Jalan Sarangan (timur), Jalan Tawangmangu (barat), Jalan Tretes (utara) dan Jalan Wijaya Kusuma dan Setaman (selatan). Terdapat banyak usaha kecil menengah dengan kriteria tertentu, yang meliputi berbagai macam bidang. Antara lain: kerajinan, produksi, home industry, dan lainlain. Berdasarkan uraian di atas, maka dibuatlah penelitian dengan judul: "Pelatihan dan Pembinaan Pengaruhnya terhadap Perkembangan Usaha Kecil”.

Rumusan masalah penelitian ini adalah: (1) Apakah terdapat pengaruh antara pelatihan dan pembinaan secara simultan terhadap pengembangan usaha kecil?; dan (2) Apakah terdapat pengaruh antara pelatihan dan pembinaan secara parsial terhadap pengembangan usaha kecil?. Adapun manfaat dari penelitian ini adalah: (1) Sebagai bahan masukan instansi terkait untuk mengembangkan program-program pelatihan bagi usaha kecil di masa datang; (2) Sebagai bahan masukan bagi usaha kecil itu sendiri agar dapat mengaplikasikan materi pelatihan yang telah diterima agar usahanya bisa lebih berkembang; dan (3) Sebagai bahan referensi bagi penelitian selanjutnya yang membahas masalah serupa.

\section{TINJAUAN PUSTAKA}

\section{Tinjauan Penelitian Terdahulu}

Alhempi, Raden et al (2013) dalam penelitiannya yang membahas tentang pengaruh pelatihan dan pembinaan terhadap pengembangan usaha kecil pada program kemitraan Bina Lingkungan di Telkom Pekanbaru membuktikan bahwa pelatihan (training) dan pembinaan (coaching) baik secara individu ataupun bersama-sama memiliki pengaruh yang signifikan terhadap perkembangan usaha kecil. Dimana pembinaan memiliki pengaruh dominan yang memberikan kepuasan kerja tinggi dalam usaha kecil menengah. Fathurrohman, Nur (2016) meneliti tentang pengaruh pelatihan, modal usaha dan pendampingan terhadap kesejahteraan Mustahik di Yogyakarta. Penelitian lain dilakukan oleh Glendoh, Sentot Harman (2001) yang meneliti tentang Pembinaan dan Pengembangan Usaha Kecil. Hasil penelitian membuktikan bahwa pembinaan dan pengembangan usaha kecil sangat dibutuhkan karena sangat besar andilnya bagi Negara dan masyarakat kecil di lapisan bawah. Susilo, Bambang et al (2014) meneliti tentang pengaruh pelatihan terhadap pengembangan usaha di KUD Jember membuktikan bahwa terdapat pengaruh pelatihan terhadap peningkatan volume perkembangan usaha KUD. Begitu juga penelitian dari Sari, Ni Made Anintia Trisna (2013) yang menyimpulkan bahwa pelatihan kewirausahaan berpengaruh positif dan signifikan terhadap perilaku berwirausaha.

\section{Pelatihan}

Soeprihanto, 2001 dalam Alhempi, Raden (2013) menyatakan bahwa pelatihan adalah kegiatan untuk memperbaiki kemampuan karyawan dengan cara meningkatkan pengetahuan dari ketrampilan operasional dalam menjalankan suatu pekerjaan. Mangkunegara, Anwar Prabu (2011) berpendapat bahwa pelatihan adalah suatu proses pendidikan jangka pendek yang mempergunakan prosedur sistematis dan terorganisir dimana pegawai non manajerial mempelajari pengetahuan dan keterampilan teknis dalam tujuan terbatas. Notoadmodjo, Soekidjo (2009) mengatakan pelatihan merupakan bagian dari suatu proses pendidikan yang tujuannya untuk meningkatkan kemampuan atau memperoleh keterampilan khusus bagi seseorang atau sekelompok orang. Hamalik (2007) menambahkan bahwa pelatihan merupakan suatu fungsi manajemen yang perlu dilaksanakan terus menerus dalam rangka pembinaan ketenagakerjaan suatu organisasi. Dari beberapa definisi di atas dapat disimpulkan bahwa pelatihan merupakan suatu proses pembinaan, pengertian dan pengetahuan terhadap sekelompok fakta, aturan, serta metode yang terorganisasikan dengan mengutamakan pembinaan kejujuran dan ketrampilan operasional.

Menurut Hamalik (2007), tujuan umum pelatihan adalah: (1) Untuk mengembangkan keahlian, sehingga pekerjaan dapat diselesaikan dengan lebih cepat dan lebih efektif. (2) Untuk mengembangkan pengetahuan, sehingga pekerjaan dapat diselesaikan secara rasional. (3) Untuk mengembangkan sikap, sehingga menimbulkan kemauan kerjasama dengan teman-teman pegawai dan manajemen (pimpinan). Adapun tujuan khusus pelatihan adalah: (1) Tujuan latihan induksi, yaitu untuk membantu pegawai menyelesaikan pekerjaannya yang baru dan untuk memberikan beberapa ide mengenai perusahaan dan latar belakang pekerjaannya. (2) Tujuan latihan kerja, yaitu untuk memberikan instruksi khusus guna melaksanakan tugas-tugas dari suatu jabatan tertentu. (3) Tujuan latihan pengawas, yaitu untuk memberikan pelajaran kepada pegawai tentang bagaimana memeriksa dan mengawasi serta melatih pegawai-pegawai lainnya. (4) Tujuan latihan manajemen, yaitu untuk 
memberikan latihan yang diperlukan dalam jabatan manajemen puncak (misal : akuntan, sekretaris, dll). (5) Tujuan latihan pengembangan pemimpin adalah untuk mengembangkan dan menambah kemampuan pemimpin-pemimpin yang sudah ada.

Menurut Hamalik (2007) program pelatihan meliputi unsur-unsur sebagai berikut: (1) Peserta latihan. Penetapan calon peserta latihan erat kaitannya dengan keberhasilan proses pelatihan yang nantinya turut menentukan efektifitas pekerjaan. Oleh karena itu perlu dilakukan seleksi yang teliti untuk memperoleh peserta yang baik berdasarkan kriteria antara lain : jenjang pendidikan dan keahlian, jabatan, pengalaman kerja, motivasi dan minat, pribadi serta intelektual; (2) Pelatih (instruktur). Pelatih memegang peran penting terhadap kelancaran dan keberhasilan program pelatihan. Itu sebabnya perlu dipilih pelatih yang ahli, berkualifikasi dan profesional. Beberapa syarat sebagai pertimbangan adalah: telah disiapkan secara khusus sebagai pelatih, ahli di bidang spesialisasi tertentu, berkepribadian baik, berasal dari lingkungan dalam organisasi (lebih baik daripada berasal dari luar organisasi); (3) Lamanya pelatihan. Lamanya masa pelatihan berdasarkan pertimbangan tentang: jumlah dan mutu kemampuan yang hendak dipelajari di pelatihan tersebut, kemampuan belajar para peserta dalam pelatihan, serta media pengajaran; (4) Bahan latihan. Bahan latihan sebaiknya disiapkan secara tertulis agar mudah dipelajari peserta. Cara penulisannya agar disesuaikan dengan buku pedoman penulisan karya ilmiah yang berlaku; dan (5) Bentuk pelatihan. Bentuk pelatihan yang digunakan untuk mengembangkan kemampuan pegawai antara lain : learning on the job, problem solving, belajar melalui observasi, kuliah, latihan, penyuluhan, kursus studi, seminar, pengajaran dengan mesin, permainan bisnis, rotasi jabatan, program pengembangan manajemen, task force, dan lain-lain.

\section{Pembinaan}

Dalam Peraturan Pemerintah RI nomor 32 tahun 1998, pembinaan dan pengembangan usaha kecil dilakukan oleh pemerintah, dunia usaha dan masyarakat, baik sendiri-sendiri maupun bersama-sama, dan dilakukan secara terarah dan terpadu serta berkesinambungan untuk mewujudkan usaha kecil yang tangguh dan mandiri, serta dapat berkembang menjadi usaha menengah. Menurut Widjaja, 2002 (dalam Alhempi, Raden, 2013), pembinaan adalah suatu proses atau pengembangan yang mencakup urut-urutan pengertian, diawali dengan mendirikan, menumbuhkan, memelihara pertumbuhan tersebut yang disertai usaha-usaha perbaikan, menyempurnakan dan mengembangkannya. Dari definisi di atas dapat disimpulkan bahwa pembinaan adalah upaya yang dilakukan pemerintah, dunia usaha dan masyarakat melalui pemberian bimbingan dan penyuluhan untuk menumbuhkan dan meningkatkan kemampuan usaha kecil agar menjadi usaha yang tangguh dan mandiri serta dapat berkembang menjadi usaha menengah.

Dalam Peraturan Pemerintah RI Nomor 32 tahun 1998 diatur mengenai beberapa hal. Pembinaan dan pengembangan usaha kecil dilakukan oleh pemerintah, dunia usaha dan masyarakat, baik secara sendiri-sendiri maupun bersama-sama dan dilakukan secara terarah, terpadu dan berkesinambungan. Pembinaan dan pengembangan usaha kecil dilakukan dengan cara-cara sebagai berikut: (1) Identifikasi potensi dan masalah yang dihadapi oleh usaha kecil, (2) Penyiapan program pembinaan dan pengembangan sesuai potensi dan masalah yang dihadapi oleh usaha kecil, (3) Pelaksanaan program pembinaan dan pengembangan, dan (4) Pemantauan dan pengendalian pelaksaan program pembinaan dan pengembangan bagi usaha kecil. Pembinaan dan pengembangan usaha kecil yang dilaksanakan oleh dunia usaha dan masyarakat berupa: (1) Penyediaan tenaga konsultan profesional, sarana, prasarana, teknologi, dana dan informasi, (2) Bimbingan dan konsultan, (3) Pendidikan dan pelatihan, (4) Advokasi, dan (5) Pendirian klinik konsultasi bisnis untuk usaha kecil.

Menurut Dewi, 2008 dalam Alhampi, Raden (2013), kegiatan pembinaan tidak terlepas dari adanya faktor pendukung dan faktor penghambat. Faktor pendukung meliputi: (1) Ketersediaan dana, (2) Jalinan kerjasama dengan instansi lain, dan (3) Ketersediaan sarana dan prasarana. Sedangkan faktor penghambat pembinaan antara lain: (1) Keterbatasan sumber daya manusia, (2) Ketidakmampuan pengusaha mengembalikan pinjaman, (3) Keterbatasan jumlah pegawai, dan (4) Keterbatasan informasi.

\section{Pengembangan Usaha Kecil}

Moekijat (1991) berpendapat bahwa pengembangan adalah setiap usaha untuk memperbaiki pelaksanaan pekerjaan yang sekarang maupun yang akan datang dengan memberikan informasi, mempengaruhi sikap atau menambah kecakapan. Kellog (dalam 
Moekijat, 1991) merumuskan bahwa pengembangan sebagai suatu perubahan dalam orang yang memungkinkan yang bersangkutan bekerja lebih efektif. Cushway, Barry menjelaskan bahwa pengembangan adalah memberikan individu pengetahuan, keahlian dan pengalaman yang perlu supaya mereka dapat melaksanakan peranan dan tanggungjawab yang lebih besar dan lebih menuntut kemampuan mereka. Berdasarkan dari beberapa definisi di atas dapat disimpulkan bahwa pengembangan adalah setiap kegiatan yang dimaksudkan untuk mengubah perilaku yang terdiri dari pengetahuan, kecakapan dan sikap. Hasil pengembangan adalah : (1) Pegawai memiliki pengetahuan atau informasi baru, (2) Dapat menerapkan pengetahuan lama dengan cara baru, dan (3) Mempunyai minat yang lebih besar untuk menerapkan apa yang ia ketahui. Arah pengembangan adalah mengembangkan karyawan sekarang dan mendatang untuk tugas-tugas masa depan dengan organisasi atau memecahkan masalah organisasi.

Menurut Bank Indonesia, usaha kecil adalah suatu usaha yang memiliki total asset maksimal Rp 600.000.000,- tidak termasuk rumah dan tanah yang ditempati. Menurut Biro Pusat Statistik adalah sebagai berikut: (1) Usaha rumah tangga, yaitu mempunyai 1-5 tenaga kerja; (2) Usaha kecil, yaitu mempunyai 6-19 tenaga kerja; (3) Usaha menengah, yaitu mempunyai 20-99 tenaga kerja; dan (4) Usaha besar, yaitu mempunyai 100 lebih tenaga kerja. Berdasarkan Undang-Undang Republik Indonesia nomor 9 tahun 1995, usaha kecil adalah kegiatan ekonomi berskala kecil yang memiliki kriteria kekayaan bersih atau hasil penjualan tahunan, dengan ketentuan sebagai berikut: (1) Memiliki kekayaan bersih paling banyak Rp 200.000.000,- (dua ratus juta rupiah) tidak termasuk tanah dan bangunan tempat usaha; (2) Memiliki hasil penjualan tahunan paling banyak Rp 1.000.000.000,- (satu milyar rupiah); (3) Milik warga Negara Indonesia; (4) Berdiri sendiri, bukan merupakan anak perusahaan atau cabang perusahaan yang dimiliki, dikuasai atau berafiliasi baik langsung maupun tidak langsung dengan usaha menengah atau usaha besar; dan (5) Berbentuk usaha orang perorangan, badan usaha yang tidak berbadan hukum, atau badan usaha yang berbadan hukum, termasuk koperasi.

Menurut Hafsah, 2004 dalam Alhempi, Raden (2013) bahwa upaya untuk pengembangan usaha kecil pada hakekatnya merupakan tanggung jawab bersama antara pemerintah dan masyarakat. Ke depannya perlu diupayakan halhal sebagai berikut: (1) Penciptaan iklim usaha yang kondusif, (2) Bantuan permodalan, (3) Perlindungan Usaha, (4) Pengembangan Kemitraan, (5) Pelatihan, (6) Membentuk Lembaga Khusus, (7) Memantapkan Asosiasi, (8) Mengembangkan promosi, dan (9) Mengembangan Kerjasama yang Setara.

\section{Hipotesis Penelitian}

Berdasarkan paparan teori dan tinjauan empiris di atas, maka dapat disusun model hipotesis penelitian sebagai berikut:

$\mathrm{H}_{1}$ : Diduga pelatihan dan pembinaan memiliki pengaruh secara simultan terhadap pengembangan usaha kecil.

$\mathrm{H}_{2}$ : Diduga pelatihan dan pembinaan memiliki pengaruh secara parsial terhadap pengembangan usaha kecil.

Gambar 1: Model Hipotesis

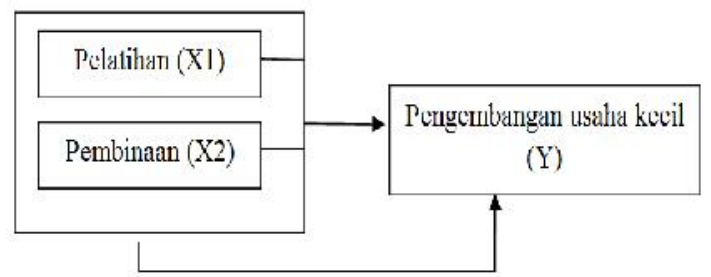

\section{METODE PENELTIAN}

Jenis Penelitian

Penelitian ini dilakukan untuk melakukan analisa secara sitematis untuk menyelesaikan masalah-masalah yang terjadi. Jenis penelitian yang akan dilakukan adalah penelitian korelasional, yaitu suatu penelitian untuk mengetahui hubungan dan tingkat hubungan antara dua variabel atau lebih tanpa ada upaya untuk mempengaruhi variabel tersebut sehingga tidak terdapat manipulasi variabel (Sugiyono, 2008). Penelitian korelasional menggunakan instrumen untuk menentukan apakah, dan untuk tingkat apa, terdapat hubungan antara dua variabel atau lebih yang dapat dikuantitatifkan.

\section{Populasi dan Sampel Penelitian}

Menurut Sugiyono (2008), populasi adalah wilayah generalisasi terdiri atas obyek/subyek yang mempunyai kualitas dan karakteristik tertentu. ditetapkan oleh peneliti untuk dipelajari dan kemudian ditarik kesimpulan. Populasi penelitian ini adalah para pengusaha usaha kecil di wilayah Kelurahan Lowokwaru Malang sejumlah 168 usaha.

Menurut Sugiyono (2008) sampel adalah sebagian dari jumlah dan karakteristik yang dimiliki oleh populasi. Tehnik pengambilan 
sampel menggunakan Purposive Sampling, yaitu pengambilan sampel dengan menggunakan kriteria tertentu. Adapun kriteria yang ditetapkan adalah usaha kecil menengah pernah mendapatkan pelatihan. Dari kriteria tersebut, maka sampel penelitian adalah sejumlah 76 usaha.

\section{Variabel Penelitian dan Pengukuran Pelatihan (X1)}

Yaitu bagian dari suatu proses pendidikan yang tujuannya untuk meningkatkan kemampuan atau memperoleh keterampilan khusus bagi seseorang atau sekelompok orang. Adapun item-itemnya sebagai berikut: Pelatih (trainer), Materi pelatihan, Metode pelatihan, Lama pelatihan, dan Tujuan pelatihan.

\section{Pembinaan (X2)}

Pembinaan adalah upaya yang dilakukan pemerintah, dunia usaha dan masyarakat melalui pemberian bimbingan dan penyuluhan untuk menumbuhkan dan meningkatkan kemampuan usaha kecil agar menjadi usaha yang tangguh dan mandiri serta dapat berkembang menjadi usaha menengah. Adapun item-itemnya sebagai berikut: Penyediaan tenaga konsultan professional, Penyediaan sarana, prasarana, teknologi, dana dan informasi, Bimbingan dan konseling, Pendirian klinik konsultasi bisnis untuk usaha kecil, dan Jalinan kerjasama dengan instansi lain

\section{Pengembangan Usaha Kecil (Y)}

Yaitu suatu perubahan dalam orang yang memungkinkan yang bersangkutan bekerja lebih efektif. Adapun item-itemnya meliputi: Penciptaan iklim usaha yang kondusif, Bantuan permodalan, Hasil usaha yang lebih meningkat, Pengembangan kemitraan, Mengembangkan promosi

Pengukuran menggunakan Skala Likert dengan ketentuan: (1) Skor 1 "Sangat tidak setuju", (2) Skor 2 "Tidak setuju", (3) Skor 2 "Cukup setuju", (4) Skor 4 "Setuju", dan (5) Skor 5 "Sangat setuju".

\section{Uji Validitas dan Uji Reliabilitas}

Uji validitas digunakan untuk mengetahui seberapa cermat suatu tes melakukan fungsi ukurnya. Adapun rumus teknik korelasi product moment adalah sebagai berikut (Umar, 2002: 190).

$r_{x y}=\frac{N \sum x y-\left(\sum x\right)\left(\sum y\right)}{\sqrt{N \sum x y^{2}-\left(\sum x\right)^{2}\left(N \sum y^{2}-\left(\sum y\right)^{2}\right)}}$
Keterangan :

$\mathrm{r}_{\mathrm{xy}}=$ Koefisien korelasi antara variabel $\mathrm{x}$ dan y

$\mathrm{y}=$ Skor item total

$\mathrm{X}=$ Skor pertanyaan

$\mathrm{N}=$ Jumlah pertanyaan

Jika $r$ hitung lebih besar dari $r$ tabel atau nilai $r$ positif dan lebih kecil dari 0,05 maka butir atau pertanyaan atau indikator tersebut dinyatakan valid. (Ghozali, 2005 : 45)

\section{Uji Reliabilitas}

Tingkat keandalan kuesioner harus reliabel atau ketepatan, apabila dicobakan secara berulangulang kepada kelompok yang sama akan menghasilkan data yang sama. Rumusnya adalah:

$$
r_{11}=\frac{2 x r_{1 / 21 / 2}}{\left(1+r_{1 / 21 / 2}\right)}
$$

Keterangan :

$\mathrm{r}_{11} \quad=$ Reliabilitas yang dicari

$\mathrm{r}^{1 / 2} \frac{1}{2}=$ Koefisien antara skor-skor setiap belahan test

Suatu konstruk atau variabel dikatakan reliabel jika memberikan nilai Cronbach Alpha $>$ 0,60. (Ghozali, $2005:$ 42)

\section{Uji Asumsi Klasik}

Uji Normalitas

Uji normalitas bertujuan untuk menguji apakah dalam model regresi, variabel pengganggu atau residual memiliki distribusi normal. Model regresi yang baik adalah yang memiliki distribusi secara normal. Uji Normalitas menggunakan Normal P-Plot (Ghozali, 2005).

\section{Uji Heteroskedastisitas}

Uji heteroskedastisitas bertujuan menguji apakah dalam model regresi terjadi ketidaksamaan variance dari residual satu pengamatan ke pengamatan yang lain. Untuk mendeteksi adanya atau tidaknya heteroskedastisitas digunakan Scatter Plot. Model regresi yang baik adalah tidak terjadi heteroekedastisitas. Jika data tersebar di atas dan di bawah garis diagonal nol, maka dikatakan tidak terjadi heteroskedasitisas (Ghozali, 2005:63)

\section{Uji Multikolinearitas}

Uji mulitikolineritas bertujuan untuk menguji apakah model regresi ditemukan adanya korelasi antar variabel bebas (independen). Model regresi yang baik seharusnya tidak terjadi korelasi di antara variabel independen. Kriteria untuk menentukan mulitikolinearitas adalah jika nilai tolerance $<0,1$ dan Varian Inflation Factor (VIF) > 10, maka terdapat 
multikolonieritas. Model regresi yang baik adalah tidak adanya multikolonieritas. (Ghozali, 2005 : 64)

\section{Pengujian Hipotesis}

Uji $t$

Uji statistik $\mathrm{t}$ dilakukan untuk mengetahui pengaruh dari masing-masing variabel independen terhadap variabel dependen (Ghozali, 2005). Pengujian ini memiliki beberapa tahap, yaitu:

1. Hipotesis ditentukan dengan formula nol secara statistik, diuji dalam bentuk:

a) Jika $\mathrm{H} 1: \beta 1>0$, berarti ada pengaruh yang signifikan antara variabel dependen dan independen secara parsial.

b) Jika $\mathrm{H} 1: \beta_{1}=0$, berarti tidak ada pengaruh signifikan antara variabel dependen dan independen secara parsial.

2. Menghitung nilai sig $t$ dengan rumus $=$

$$
T \text { hitung }=\frac{\beta i}{s e(\beta i)}
$$

Dimana :

$\beta i=$ Koefisien regresi

\section{se $(\beta i)=$ standar error dari estimasi $\beta \mathrm{i}$}

3. Derajat keyakinan (level significance / $\alpha=$ $5 \%$ )

a) Apabila besarnya nilai sig $t$ lebih besar dari tingkat alpha yang digunakan, maka hipotesis yang diajukan, ditolak.

b) Apabila besarnya nilai sig $t$ lebih kecil dari tingkat alpha yang digunakan, maka hipotesis yang diajukan, diterima.

Uji F

Uji statistik $F$ digunakan untuk mengetahui pengaruh antara variabel independen secara simultan terhadap variabel dependen (Ghozali, 2005). Uji ini memiliki beberapa tahap, yaitu:

1. Hipotesis ditentukan dengan formula nol secara statistik, diuji dalam bentuk:

a) Jika $\mathrm{H} 1$ : $\beta 1=\beta 2=\ldots=0$, berarti tidak ada pengaruh yang signifikan antara variabel dependen dan independen secara simultan.

b) Jika $\mathrm{H} 1: \beta 1 \neq \beta 2 \neq . . \neq 0$, berarti ada pengaruh signifikan antara variabel dependen dan independen secara simultan.

2. Menghitung nilai sig $t$ dengan rumus :

$\frac{R^{2} /(k-1)}{\left(1-R^{2}\right) /(N-k)}$

Dimana :

$\mathrm{R}^{2}=$ Koefisien determinasi

$K=$ Nilai variabel

$N=$ Nilai observasi
3. Derajat keyakinan ( level significance / $\alpha=$ $5 \%$ )

a) Apabila nilai signifikansi $\mathrm{F}$ hitung lebih besar dari nilai $\mathrm{F}$ tabel, maka hipotesis alternatif diterima.

b) Apabila nilai signifikansi $F$ hitung lebih kecil dar nilai $F$ tabel maka hipotesis alternatif ditolak.

Koefisien determinasi $(R)$

Koefisien determinasi $\left(\mathrm{R}^{2}\right)$ digunakan untuk menunjukkan sampai seberapa besar variasi variabel dependen yang dapat dijelaskan oleh variabel-variabel independen yang ada dalam model (Ghozali, 2005 : 42). Nilai $R^{2}$ mempunyai range antara $0-1$, jika nilai range semakin mendekati angka 1 maka variabel independen. Besarnya nilai $\mathrm{R}^{2}$ dapat diperoleh dengan menggunakan rumus sebagai berikut :

$R^{2}=\frac{E S S}{T S S}=1-\frac{R S S}{T S S}$ Gujarati, $2003: 217$

Keterangan :

ESS = Explained sum of square (jumlah kuadrat dari regresi)

TSS = Total sum square (total jumlah kuadrat)

RSS = Residual sum square (jumlah kuadrat kesalahan penggangu).

HASIL PENELITIAN DAN PEMBAHASAN Uji Validitas dan Reliabilitas

Uji validitas digunakan untuk mengethui seberapa cermat suatu tes melakukan fungsi ukurnya. Adapun hasil uji validitas dapat dilihat pada tabel di bawah ini.

Tabel 1. Uji Validitas

\begin{tabular}{ll|cc|c}
\hline No & Item & I-hitung & r-tabel & Ketetangan \\
1 & $\mathrm{X} 1.1$ & 0,476 & 0,15 & Valid \\
\hline 2 & $\mathrm{X} 1.2$ & 0,407 & 0,15 & Valid \\
\hline 3 & $\mathrm{X} 1.3$ & 0,423 & 0,15 & Valid \\
\hline 4 & $\mathrm{X} 1.4$ & 0,645 & 0,15 & Valid \\
5 & $\mathrm{X} 1.5$ & 0,527 & 0,15 & Valid \\
\hline 6 & $\mathrm{X} 2.1$ & 0,459 & 0,15 & Valii \\
\hline 7 & $\mathrm{X} 2.2$ & 0,101 & 0,15 & Valid \\
\hline 8 & $\mathrm{X} 2.3$ & 0,823 & 0,15 & Valid \\
\hline 9 & $\mathrm{X} 2.4$ & 0,321 & 0,15 & Vulid \\
\hline 10 & $\mathrm{X} 2.5$ & 0,703 & 0,15 & Valid \\
\hline 11 & $\mathrm{Y} 1.1$ & 0,680 & 0,15 & Valid \\
\hline 12 & $\mathrm{Y} 1.2$ & 0,721 & 0,15 & Valid \\
13 & $\mathrm{Y} 1.3$ & 0,601 & 0.15 & Valid \\
\hline 14 & $\mathrm{Y} 1.4$ & 0,687 & 0,15 & Valid \\
\hline 15 & $\mathrm{Y} 1.5$ & 0,706 & 0,15 & Valid \\
\hline
\end{tabular}

Sumber: hasil olah data penelitian, 2017

Dari tabel di atas diketahui bahwa nilai $r$ hitung $>\mathrm{r}$ tabel, sehingga semua item variabel dinyatakan valid.

Uji Reliabilitas adalah tingkat keandalan kuesioner harus reliabel atau ketepatan, apabila dicobakan secara berulang-ulang kepada 
kelompok yang sama akan menghasilkan data yang sama. Adapun hasil uji reliabilitas dapat dilihat pada tabel di bawah ini:

Tabel 2: Uji Reliabilitas

\begin{tabular}{|c|c|c|c|}
\hline Vo liarialsel & $\begin{array}{l}\text { Alphtia } \\
\text { Conothath }\end{array}$ & Alphtia & Ketpraingall \\
\hline $\mathrm{X} 1$ & 0.852 & 0,6 & Redingel \\
\hline $\mathrm{X}$ & $0,6,63$ & 0,0 & Raliabel \\
\hline $3 \quad X 3$ & 0,790 & 0,0 & Reliabel \\
\hline
\end{tabular}

Sumber: hasil olah data penelitian, 2017

Dari tabel di atas diketahui bahwa semua nilai Cronbach's Alfa > 0,6. Berarti seluruh item variabel penelitian semuanya reliable dan dapat dilanjutkan ke uji berikutnya.

\section{Uji Asumsi Klasik}

\section{Uji Normalitas}

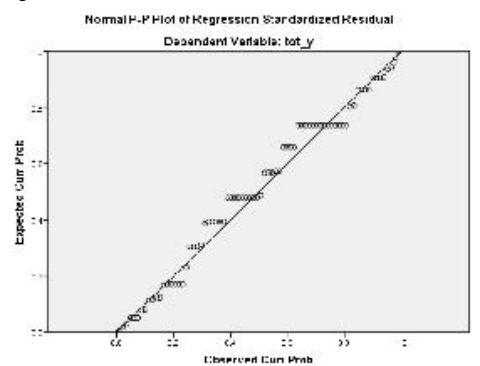

Gambar 2: Normal P-Plot

Dari gambar di atas diketahui bahwa seluruh data berada di sekitar garis diagonal. Berarti semua data penelitian berdistribusi normal.

Uji Multikolinieritas

Tabel 3: Uji Multikolinieritas

\begin{tabular}{|l|c|c|}
\hline No & Variabel & VIF \\
\hline 1 & $\mathrm{X} 1$ & 1.889 \\
\hline 2 & $\mathrm{X} 2$ & 1.889 \\
\hline
\end{tabular}

Sumber: olah data penelitian, 2017

Dari tabel di atas diketahui bahwa nilai VIF adalah $1.889<10$, maka tidak terdapat korelasi antar variabel independen, atau dengan kata lain terbebas dari multikolinieritas

Uji Heteroskedastisitas

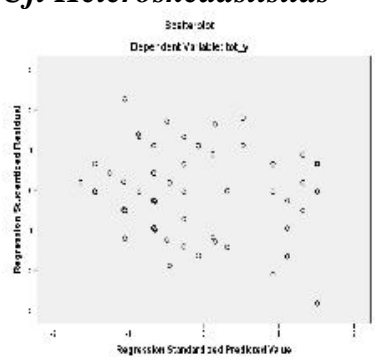

Gambar 3: Scatterplot

Dari gambar Scatter Plot di atas diketahui bahwa data tersebar rata di atas dan di bawah garis diagonal dan tidak membentuk suatu pola tertentu. Berarti data terbebas dari heteroskedastisitas.

\section{Uji Regresi Berganda}

Tabel 4: Hasil Uji Regresi Berganda Model Summary

\begin{tabular}{|l|r|r|r|r|}
\hline Model & $R$ & R Square & $\begin{array}{c}\text { Adjusted R } \\
\text { Square }\end{array}$ & $\begin{array}{r}\text { Std. Error of } \\
\text { the Estimate }\end{array}$ \\
\hline 1 & $.759^{2}$ & .576 & .564 & 1.46835 \\
\hline
\end{tabular}

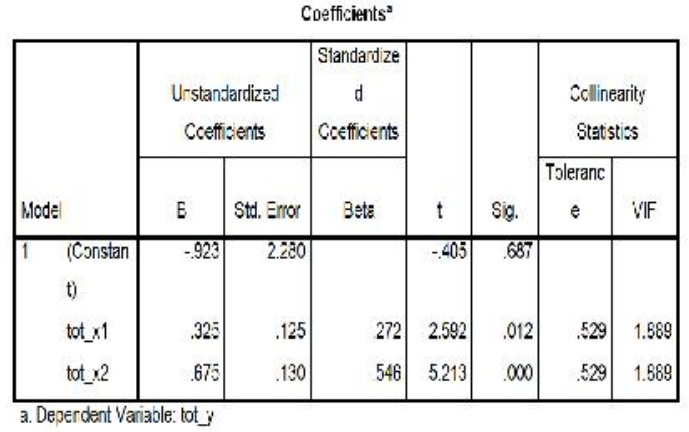

Sumber: olah data penelitian, 2017

Dari Model Summary diketahui bahwa nilai $\mathrm{R}$ sebesar 0,759 menunjukkan bahwa terdapat hubungan yang kuat antara pelatihan dan pembinaan terhadap pengembangan usaha kecil, karena angkanya mendekati 1. Sedangkan Koefisien Determinasi (R square) memiliki nilai sebesar 0,576 menunjukkan bahwa pengembangan usaha kecil dijelaskan oleh pelatihan dan pembinaan sebesar $57,6 \%$, sedangkan sisanya dijelaskan oleh variabel lain yang tidak diteliti dalam penelitian ini. Misalnya: motivasi, disiplin kerja, lingkungan kerja, dan lain-lain. Dari uji ANOVA atau uji $\mathrm{F}$, didapatkan hasil $\mathrm{F}$ hitung sebesar 49.525 dengan nilai signifikasi sebesar 0.000 . Hal ini menunjukkan bahwa secara simultan pelatihan dan pengembangan memiliki pengaruh terhadap pengembangan usaha kecil. Berarti hipotesis satu diterima.

Persamaan regresi penelitian ini adalah sebagai berikut:

$\mathrm{Y}=\mathrm{a}+\beta 1 \mathrm{X} 1+\beta 2 \mathrm{X} 2+\mathrm{e}$

$\mathrm{Y}=0,923+0,325 \mathrm{X} 1+0,675 \mathrm{X} 2+\mathrm{e}$

Uji t digunakan untuk menguji signifikansi konstanta dan setiap variabel independen. Dari tabel Coefficient, diketahui bahwa nilai t hitung variabel pelatihan (2.592) > t tabel $(1,29)$ dengan nilai signifikansi 0.000. Sedangkan nilai $\mathrm{t}$ hitung variabel pembinaan $(5.213)>\mathrm{t}$ tabel (1.29) dengan nilai siginifikasni 0.000 . Hal ini menunjukkan bahwa pelatihan dan pembinaan secara parsial memiliki pengaruh terhadap pengembangan usaha kecil. Berarti hipotesis kedua diterima. Adapun variabel yang dominan 
berpengaruh adalah pembinaan (X2) dengan nilai beta terbesar sebesar 0.675 .

\section{PEMBAHASAN}

Pelatihan bertujuan untuk mengembangkan keahlian, sehingga pekerjaan dapat diselesaikan dengan lebih cepat dan efektif dan untuk mengembangkan pengetahuan, sehingga pekerjaan dapat dilakukan secara rasional. Kegiatan pelatihan pada dasarnya dilaksanakan untuk menghasilkan perubahan tingkah laku dari orang-orang yang mengikuti pelatihan. Perubahan tingkah laku yang dimaksud adalah dapat berupa tambahnya pengetahuan, keahlian, keterampilan dan perubahan sikap dan perilaku. Pelatihan sangatlah penting untuk meningkatkan kreativitas, keterampilan dan pengetahuan para pemilik dan karyawan usaha kecil menengah dalam menjalankan bisnisnya agar dapat mengembangkan usahanya lebih maju lagi.

Selain pelatihan, pembinaan usaha kecil pun harus dilakukan, agar kegiatan usaha dapat berkembang menjadi lebih luas lagi. Usaha kecil sebagai kegiatan ekonomi rakyat berskala kecil memiliki peran sentral dalam perekonomian Indonesia. Oleh karenanya dibutuhkan sekali adanya pembinaan.

Peningkatan produktivitas pada usaha kecil akan berdampak luas pada perbaikan kesejahteraan rakyat karena usaha kecil adalah tempat dimana banyak orang menggantungkan sumber kehidupannya. Salah satu alternatif dalam meningkatkan produktivitas dan pengembangan usaha kecil adalah dengan modernisasi sistem usaha dan perangkat kebijakannya yang sistematik sehingga akan memberikan dampak yang lebih luas lagi dalam meningkatkan daya saing daerah. Hasil penelitian ini didukung oleh penelitian Glendoh (2001), Alhempi (2013), Fathurrohman (2016), Susilo (2014) dan Sari (2013).

\section{KESIMPULAN DAN SARAN Simpulan}

(1) Tujuan penelitian ini adalah untuk menguji pengaruh pelatihan dan pembinaan secara simultan dan parsial terhadap pengembangan usaha kecil; (2) Sampel penelitian adalah 76 orang pengusaha kecil menengah di Kelurahan Lowokwaru Malang, dengan teknik pengambilan sampel Purposive Sampling. Adapun kriteria syaratnya adalah pengusaha tersebut telah mengikuti pelatihan; (3) Hasil uji validitas dan realibitas, seluruh item-item variabel sudah valid karena nilai $r$ hitung $>r$ tabel $(0,15)$, serta sudah realiabel karena seluruh nilai Alpha Cronbach nya di atas 0,6; (4) Hasil uji asumsi klasik membuktikan bahwa seluruh data penelitian sudah berdistribusi normal (menggunakan Normal P-Plot dimana seluruh data berada pada garis diagonal), dan terbebas dari adanya multikolinieritas (nilai VIF di atas 10) dan heteroskedastisitas (menggunakan Scatter Plot dimana seluruh data menyebar rata di atas sumbu nol dan tidak membentuk pola tertentu); (5) Nilai $\mathrm{R}$ sebesar 0,759 menunjukkan bahwa terdapat hubungan yang kuat antara pelatihan dan pembinaan terhadap pengembangan usaha kecil, karena angkanya mendekati 1. Sedangkan Koefisien Determinasi (R square) memiliki nilai sebesar 0,576 menunjukkan bahwa pengembangan usaha kecil dijelaskan oleh pelatihan dan pembinaan sebesar 57,6\%, sedangkan sisanya dijelaskan oleh variabel lain yang tidak diteliti dalam penelitian ini. Misalnya: motivasi, disiplin kerja, lingkungan kerja, dan lain-lain; (6) Dari uji ANOVA atau uji $\mathrm{F}$, didapatkan hasil $\mathrm{F}$ hitung sebesar 49.525 dengan nilai signifikasi sebesar 0.000 . Hal ini menunjukkan bahwa secara simultan pelatihan dan pengembangan memiliki pengaruh terhadap pengembangan usaha kecil. Berarti hipotesis satu diterima; dan (7) Nilai t hitung variabel pelatihan $(2.592)>t$ tabel $(1,29)$ dengan nilai signifikansi 0.000 . Sedangkan nilai $\mathrm{t}$ hitung variabel pembinaan (5.213) $>\mathrm{t}$ tabel (1.29) dengan nilai siginifikasni 0.000 . Hal ini menunjukkan bahwa pelatihan dan pembinaan secara parsial memiliki pengaruh terhadap pengembangan usaha kecil. Berarti hipotesis kedua diterima. Adapun variabel yang dominan berpengaruh adalah pembinaan (X2) dengan nilai beta terbesar sebesar 0.675 .

\section{Saran-saran}

(1) Pengusaha memperbanyak mengikuti pelatihan-pelatihan baik yang diadakan oleh pemerintah dalam hal ini di wilayah Kelurahan Lowokwaru Malang, ataupun oleh pihak swasta. Karena dengan pelatihan akan dapat membuka wawasan mereka untuk dapat lebih mengembangkan lagi usaha mereka di masa depan; (2) Pihak Kelurahan Lowokwaru Malang menjembatani atau memfasilitasi akan kebutuhan para pengusaha kecil ini untuk mencarikan narasumber yang kompeten di bidangnya, baik untuk memberikan pelatihan, seminar ataupun workshop kepada para pengusaha. Sehingga mereka memperoleh pengetahuan praktis sesuai dengan bidang usaha yang dapat memberikan pinjaman soft loan, atau dengan kegiatan seminar ataupun digeluti, dan dapat mengimplementasikannya secara baik dan terarah; (3) Perusahaan ataupun lembaga keuangan dapat memberikan fasilitas pendanaan atau CSR (corporate social responsibility) 
kepada para pengusaha kecil untuk workshop yang disponsori oleh mereka sehingga para pengusaha kecil memperoleh banyak sekali ilmu baru yang uptodate sehingga bisa lebih percaya diri dan termotivasi untuk berusaha dan mengembangkan usaha mereka ke depan; dan (4) Berkaitan dengan pembinaan usaha kecil, diharapkan pihak Kelurahan Lowokwaru ataupun instansi terkait lainnya dapat melakukan beberapa pilihan tindakan, misalnya: Penyediaan informasi, bantuan manajemen dan teknologi kepada usaha kecil, Pemberian bimbingan dan konsultasi melalui klinik konsultasi bisnis kepada usaha kecil, Pelaksanaan magang, studi banding dan praktek kerja bagi usaha kecil, Lembaga keuangan menyediakan pendanaan usaha kecil dan menyederhanakan tata cara memperoleh pendaan sehingga mudah mengajukan permohonan kredit, dan Penyelenggaraan pelatihan membuat rencana usaha dan manajemen keuangan.

\section{DAFTAR PUSTAKA}

1. Alhempi, Raden Rudi dan Wismar Harianto, 2013, Pengaruh Pelatihan dan Pembinaan terhadap Pengembangan Usaha Kecil pada Program Kemitraan Bina Lingkungan. Media Riset Bisnis dan Manajemen, volume 13, Nomor 1, April 2013.

2. Fathurrohman, Nur, 2016, Pengaruh Pelatihan, Modal Usaha dan Pendampingan terhadap Kesejahteraan Mustahik, Universitas Islam Negeri Sunan Kalijaga Jogjakarta, Penelitian dipublikasikan, diakses tanggal 10 Januari 2017

3. Glendoh, Sentot Harman, 2001, Pembinaan dan Pengembangan Usaha Kecil, Jurnal Manajemen dan Kewirausahaan, Vol 3, no 1, Maret 2001.

4. Hamalik, Oemar (2000), Pengembangan SDM : Manajemen Pelatihan Ketenagakerjaan, Pendekatan Terpadu, Cetakan 1, Penerbit Bumi Aksara, Jakarta.

5. Moekijat (1991), Latihan dan Pengembangan Sumber Daya Manusia, Cetakan 4, Penerbit Mandar Maju, Bandung

6. Sari, Ni Made Anintia Trisna, 2013, Pengaruh Pelatihan, sikap, intensi dan modal terhadap Perilaku Berwirausaha pada Peserta Program Mahasiswa Wirausaha Universitas Pendidikan Ganesha tahun 2012, Penelitian dipublikasikan, http://library.um.ac.id, diakses tanggal 10 Januari 2017.
7. Susilo, Bambang, Hendra Wijaya, dan Nanik Yuliati, 2014. Pengaruh Pelatihan terhadap Pengembangan Usaha di KUD Marem Desa Serut Kecamatan Panti Kabupaten Jember Tahun 2013, Penelitian dipublikasikan, diakses tanggal 10 Januari 2017. 